\title{
The Glass Cage: The Gender Pay Gap and Self-Employment in the United States
}

\author{
Leanna Lawter \\ Tuvana Rua \\ Jeanine Andreassi
}

S

elf-employment is often viewed as a more desirable work arrangement than working as an employee for a firm. Women are pushed into self-employment due to organizational factors, such as a shrinking workforce or limited job opportunities, while being attracted to self-employment by the many psychological and social benefits (e.g., independence, flexibility, work-life balance, job satisfaction). Despite more women moving into selfemployment, this type of employment still has different financial consequences for men and women. This article investigates whether a pay gap exists for self-employed women after controlling for industry, occupation, and hours worked and seeks to quantify the gender wage gap for the self-employed. A sample of 467 self-employed independent contractors in the United States was examined from the 2008 National Study of the Changing Workforce. The results indicate a large financial disparity between self-employed women and men. On average men earned $\$ 54,959$ as compared to women who earned on average $\$ 28,554$. Regardless of the parity in education, work experience, number of hours worked, or occupations, women earn less than men in self-employment. Findings suggest the existence of the glass cage - a phenomenon whereby self-employed women earn significantly less than self-employed men with limited abilities to narrow the economic inequality.

Keywords: self-employment; gender pay gap; female entrepreneurs; gender discrimination

Self-employment has been positioned as the career panacea for women. Women are pulled and pushed into self-employment as a career solution in an effort to fill the traditional role of wife and mother while earning an income. For those seeking to balance work and family, self-employment has been lauded in the media as the solution to continuing a career and caring for children. In a thought-provoking piece in the Atlantic, Anne-Marie Slaughter (2012) asserted that workplaces are not friendly toward working families, and that "the women who have managed to be both mothers and top professionals are superhuman, rich, or self-employed." Slaughter positions self-employment as an avenue that allows women to thrive combining work and family. Along the same line, in a recent New York Times article, Judith Warner (2013) describes the difficulties of women who have "opted out" to stay at home and raise families getting back into the workforce. One successful solution portrayed in the article is self-employment, where a women can work "without dropping any of her maternal duties."

For many women, there are limited job opportunities based on their lack of education, lack of experience, and demands from children and families. These women typically pursue nonprofessional jobs such as babysitting, housekeeping, dog-walking, and the proverbial Avon lady. They are pushed into these jobs by the need to work counter-balanced with demands of children and family and the lack of ability to get higher paying jobs elsewhere that offer flexibility (Budig, 2006). On the other side, professional women are increasingly opting out of careers in larger organizations into self-employment as they are confronted with a number of career challenges. Organizational downsizing and restructuring have pushed women out of careers or forced them to work as contract employees (Cox, 2013; Kotkin, 2012). Lack of promotion opportunities or career advancement (McKie, Biese, \& Jyrkinen, 2013) and frustration over balancing work and family (Hughes, 2003) have increased job dissatisfaction and lured women into self-employment. In particular for professional women, self-employment is positioned as the best of all worlds: being your own boss, pursuing your passion, having flexibility, all while earning high levels of income (Annik \& den Dulk, 2012; Prottas \& Thompson, 2006; Lombard, 2001). An underlying assumption is that self-employment will lead to increased income, a positive career trajectory, and increased flexibility (Hughes, 2003).

However, self-employment is not a career panacea for either professional or nonprofessional women, particularly with regard to financial outcomes. The current research posits that for self-employed women, the gender pay gap is a manifestation of the underlying gender inequality and 
creates a glass cage of economic inequality from which there is no escape. We hypothesize that self-employment does not close the pay gap for women as compared to men even though women work as many hours as their self-employed male counterparts. Furthermore, professional women who are using self-employment as a surrogate for part-time employment experience a punitive impact on their income such that, regardless of their occupation, they are unable to close the pay gap and end up being trapped in the glass cage.

This article seeks to extend past research on the differences in earnings for men and women in self-employment with respect to industry, occupation, and hours worked to investigate the extent to which women earn less than men in self-employment. Much of the research supports that woman are still faring worse than men are in terms of earnings within self-employment. However, this disparity has been attributed primarily to the difference in the number of hours worked by women as compared to men (Becker, 1986; Hersch \& Stratton, 1994; Hymowitz, 2012), choice of industry (Hundley, 2001; Borden, 1999), and occupation (Hipple, 2010; Georgellis \&Wall, 2005). We challenge this explanation based on a number of studies that have shown the pay gap is an embedded structural component of our labor system whereby the income inequality begins with the first job (Smith, 2012; Weinberger, 2011). We posit that the pay gap is not due solely to differences in choice of industry, occupation, or the number of hours worked, but instead is deeply rooted in a system where women are paid less at every level of employment. We seek to quantify the pay gap and provide further insight into some of the possible reasons behind the disparity in wages among self-employed women. The current research contributes to the existing literature by being the first study to quantify the financial disparity between self-employed men and women in the United States while controlling for previously identified factors that impact pay disparity. Additionally, the current study uses a large nationally sourced database, increasing the generalizability of the findings and bringing to light the existence of the glass cage.

\section{Definition of Self-Employment}

Self-employment is defined as engaging in a profession or trade to generate income but not receiving wages directly from an employer (Cox, 2013). With the increased interest in "entrepreneurship" in both economic and academic circles, there is an additional distinction among self-employed workers. Entrepreneurs by definition are typically focused on acquisition of capital and business expansion (Kao, 1993; Carland, Carland, Hoy, \& Boulton, 1998). Additionally, entrepreneurs typically have one or more employees (Blanchflower \& Oswald, 1998) and are usually legally incorporated (Hundley, 2001). Alternatively, self-employed workers are typically working as independent contractors with no employees (Blanchflower \& Oswald, 1998) or contingent workers with alternative work arrangements and no employees (Kotkin, 2012). One in three women are self-employed and an increasing number of women are opting for selfemployment over employment for others (Roche, 2014; Mattis, 2004). Although more men than women are selfemployed, self-employed women are twice as likely to be independent contractors with no employees, particularly when using self-employment as a substitute for part-time work. The current study's focus is solely on self-employed individuals who do not have any employees working for them as this represents approximately two-thirds of self-employed women (Roche, 2014).

\section{Push and Pull Factors as Reasons for Self-employment}

A number of factors, identified as push or pull factors, attract women to self-employment. Pull factors refer to elements that make self-employment more attractive over working as a waged employee for an organization (Hughes, 2003). In studies of professional women, pull factors have been related to the positive work aspect employees perceive to be actualized by self-employment. In a qualitative study in Canada, which investigated whether professional women are "pushed or pulled" into self-employment, the most important pull factors were wanting to be challenged, desiring independence, and having a positive work environment (Hughes, 2003). Flexible work schedules and the ability to balance work and family responsibilities are also commonly cited as pull justifications to self-employment (Prottas \& Thompson, 2006; Lombard, 2001). Independence and the ability to control work are also highly cited as reasons why professional women choose self-employment over working for others (McKie, Biese, \& Jyrkinen, 2013; Hughes, 2003; Lombard, 2001). Lastly, there is the expectation of higher earnings particularly for women who are more educated and have professional backgrounds (Taniguchi, 2002; Lombard, 2001; Borden, 1999). 
On the other hand, push factors are those tendencies that pressure women to self-select into self-employment instead of staying in an organization as a waged employee (Hughes, 2003). Self-employment has been increasingly used as a substitute for part-time work, particularly among women who are college educated with families, due to the lack of part-time positions in large organizations (Hipple, 2010; Georgellis \& Wall, 2005). Work and organizations have been characterized as gendered male, whereby the organization processes, work, culture, and jobs themselves are inherently in favor of men and discriminate against women (Acker, 1990). By definition work delineates "domestic life and social production" (Acker, 1990, p. 149), and assumes that women will occupy lower paying, less skilled jobs with slower mobility tracks. When women do breach what has traditionally been male-occupied positions, they are expected to function like men (Acker 2006). In these male-dominated positions, long hours, lack of flexibility and work-life balance, and the expectation of presenteeism contribute to women feeling they are being pushed out of the organization (Stone, 2007). Women often feel a sense of being "pushed" into selfemployment, due to factors that include limited career opportunities and downsizing, job stress, job insecurity, high workload, and having a bad boss (Hughes, 2003). Similarly, for women managers with more experience, overall dissatisfaction with the organization (Mallon \& Cohen, 2001) and the inability to progress in earnings and level (McKie, Biese, \& Jyrkinen, 2013) are factors that force women out of organizations.

Many women have limited choices for employment due to family and personal demands. Women are still expected to act as the primary caretaker for children and bear the primary responsibility for housework (Parker \&Wang, 2013). On average, women spend 20 to 30 hours a week performing housework while their male partners spend 10 hours a week (Parker \& Wang, 2013; Hersch \& Stratton, 1994). When children are present in the household, the amount of time a woman spends on housework increases on average by 14 hours per week while her husband's time increases on average by 7 hours per week (Parker \& Wang, 2013). Child care is viewed increasingly as a predominantly female task, and the number of hours women spend with their family has increased, putting more pressure on mothers to have "quality time" with their children (Bianchi, 2000). Parenting has also taken on a new meaning with "intensive parenting", where a parent "cultivates, informs, and monitors" (Bernstein \& Triger, 2010, p. 1221) a child to ensure the child reaches its full potential, becoming the social norm among educated white females (Bernstein \& Triger, 2010). Women are torn between being the "ideal mother" and the "ideal worker" in a no-win situation (Stone, 2007). This, in turn, negatively impacts their earnings and the decisions regarding how to allocate time between work and other domestic activities (Becker, 1986; Stone, 2007). In an effort to balance work and family, many women are pushed into nonprofessional self-employed positions, which require less skills and less education but enable them to meet the demands of childcare and housework (Budig, 2006).

\section{The Gender Pay Gap and Self-employment}

The potential of increased earnings has been identified as a perceived benefit of becoming self-employed (McKie, Biese, \& Jyrkinen, 2013; Hughes, 2003; Taniguchi, 2002; Lombard, 2001; Borden, 1999). Despite the lure of better earnings, women earn less than men in self-employment. In a longitudinal study, Borden (1999) found that choice of industry and occupation accounted for a large portion of the pay disparity and that self-employed women earned significantly less (32 cents on the dollar) than selfemployed men. Hundley $(2000,2001)$ found that women are also more likely to shoulder more of the housework and child rearing, particularly when self-employed, negatively impacting their earnings (Hundley, 2000, 2001). Both Borden (1999) and Hundley $(2000,2001)$ attributed the pay disparity to traditional factors of choice of industry and occupation, as well as other factors, such as having children. While choice of occupation, industry, and having children do explain some of the pay differential, a number of studies have demonstrated that the difference in wages between men and women is relatively equal at all points in times across a career (Smith, 2012; Weinberger, 2011).

From the start of their careers, women's wages are below their male counterparts with equal experience and equal education (Weinberger, 2011). Women do not fall behind as they progress in their careers so much as start from behind and remain at a deficit throughout their career (Weinberger, 2011). 
Therefore, we predict that even controlling for industry, occupation, hours worked, age, and education

Hypothesis 1a: Self-employed women earn less than self-employed men.

Hypothesis $\mathbf{1}$ b: Self-employed women working full time earn less than self-employed men working full time.

Hypothesis 1c: Self-employed women working part time earn less than self-employed men working part time.

One key reason attributed to the self-employed pay gap is the number of hours women work. In two different studies, Hundley $(2000,2001)$ found that women perform significantly more hours of housework and childcare, which negatively impacted their earnings. The conclusion was that the self-employed women allocated less hours to work than self-employed men in favor of performing these household duties. A number of sources are often cited that support the claim that the difference in gender income is directly attributable to number of hours worked (Becker, 1986; Hersch \& Stratton, 1994; Hymowitz, 2012). However, self-employment is often used as a substitute for part-time work, with women choosing to work less hours in order to balance work and family. In the aggregate, self-employed women work less hours than self-employed men as more women use self-employment as a parttime work arrangement (Georgellis \& Wall, 2005). In an alternative perspective, in 2007 the U.S. Bureau of Labor's "American Time Use Report"found that when reclassified by employment status (part time vs. full time), only slight differences emerged between the number of hours worked by men and women. Among full-time workers, men worked 8.2 hours a day while women worked 7.8 hours a day. Among part-time workers, men worked 5.2 hours a day while women worked 5.4 hours a day. Once reclassified as part-time and full-time workers, there was no longer a significant difference between women and men in terms of hours worked. Thus, differentiating between hours worked as part-time and full-time employment, we predict

Hypothesis 2a: The number of hours worked by self-employed women who work full time will not be significantly different from the number of hours worked by self-employed men who work full time.

Hypothesis 2b: The number of hours worked by self-employed women who work part time will not be significantly different from the number of hours worked by self-employed men who work part time.
Choice of industries is often cited as a reason for the pay gap between women and men, even in self-employment. Traditionally, more self-employed women have worked in lower paying industries, such as personal services, retail, and clerical positions, which require lower skill levels and less education than other higher paying industries, such as technology and finance (Hundley, 2001; Borden, 1999). Women are often pushed into these lower paying jobs as a means of balancing work and family while still trying to earn a living (Budig, 2006). Despite the trend for more women to work in professional and business-related industries (18.4\% of self-employed unincorporated women), the differences in earnings still exist (Roche, 2014). This persistent inequality in wages points to a more systemic gender bias in our labor markets. We put forth that regardless of industry, self-employed women will earn less than self-employed men overall. Therefore we predict that

Hypothesis 3: Self-employed women earn less than self-employed men across all industries.

Occupation is also a factor in the earning power of self-employed women. Despite their educational backgrounds, historically self-employed women will often select an occupation that requires lower skill levels and also has less earning potential (Georgellis \& Wall, 2005). Women will also transition from a managerial position in an organization to a nonmanagerial position, losing human capital in the transition, which negatively impacts their earnings (Hundley, 2001). However, more recently, women with more education and work experience are selecting self-employment and choosing to remain in managerial and professional positions (Roche, 2014; Bosse \& Taylor, 2012). Yet, the pay gap still persists overall (Roche, 2014; Hipple, 2010). We predict that due to inherent gender biases in all occupations, self-employed women will make less than their male counterparts. Furthermore, we expect to see a pay gap for both nonprofessional and professional occupations if there is a systemic gender bias across all occupations. Hence, we posit

Hypothesis 4a: Self-employed women make less than self-employed men across all occupations.

Hypothesis 4b: Self-employed professional women make less than self-employed professional men.

Hypothesis 4c: Self-employed nonprofessional women make less than self-employed nonprofessional men. 


\section{Methodology}

\section{Sample}

The sample consisted of 467 self-employed independent contractors from the 2008 National Study of the Changing Workforce (NSCW). The NSCW, which is administered every five to six years by the Families and Work Institute, employs a nationally representative sample of 3,502 U.S. households. The overall response rate for the 2008 NSCW was 54.6 percent. Surveying was conducted by telephone. Of the 467 self-employed independent contractors, 42 percent were females, the average of age across genders was 48.9 years, and the average level of education across genders was some college with 23.6 percent having a college degree. The demographics by gender are displayed in Table 1a. The distribution of participant across industries and occupations is displayed in Tables $1 \mathrm{~b}$ and $1 \mathrm{c}$, respectively. As expected, females have higher representation in traditionally female-dominated industries, such as retail and personal services. Similarly, females also have a higher representation in traditionally female-dominated occupations, such as service and administrative support.

Table 1a. Descriptive Statistics by Gender

\begin{tabular}{|c|c|c|c|c|c|}
\hline \multirow[b]{2}{*}{ Demographics } & \multicolumn{2}{|c|}{$\begin{array}{c}\text { MALE } \\
(\mathrm{N}=268)\end{array}$} & \multicolumn{2}{|c|}{$\begin{array}{c}\text { FEMALE } \\
(\mathrm{N}=198)\end{array}$} & \multirow[t]{2}{*}{$t$} \\
\hline & Mean & SD & Mean & SD & \\
\hline Usual Hours Worked & 40.73 & 17.91 & 33.09 & 16.86 & $4.25^{* *}$ \\
\hline Age & 47.38 & 12.97 & 50.40 & 13.79 & $2.19^{*}$ \\
\hline Education in Years & 13.20 & 2.03 & 13.36 & 1.78 & 0.81 \\
\hline
\end{tabular}

Table $1 \mathrm{~b}$. Industry by Gender

\begin{tabular}{lccc}
\multirow{2}{*}{ Industry } & MALE & & FEMALE \\
& $\%$ & & $\%$ \\
\hline Agriculture/Forestry/Fishing/Mining & 14.6 & 6.2 \\
Construction & 19.0 & 5.0 \\
Manufacturing & 3.1 & 2.5 \\
Transportation/Utilities & 6.6 & 2.5 \\
Wholesale Trade & 4.0 & 1.9 \\
Retail Trade & 8.0 & 18.0 \\
Finance/Insurance/Real Estate & 10.6 & 7.5 \\
Business/Repair Services & 10.2 & 10.6 \\
Personal Services & 4.0 & 12.4 \\
\hline Entertainment/Recreation & 1.3 & 1.9 \\
\hline Medical Services & 2.7 & 3.1 \\
\hline Education Services & 2.7 & 3.7 \\
\hline Other Professional Services & 11.5 & 23.0 \\
\hline Public Administration & 1.8 & 1.9 \\
\hline$x^{2}=0.8,13,000$ & & \\
\hline
\end{tabular}

$x^{2}=50.8,13, .000$ 


\section{Table 1c. Occupation by Gender}

\begin{tabular}{|c|c|c|}
\hline Occupation & $\frac{\text { MALE }}{\%}$ & FEMALE \\
\hline Executives/Administrators/Managers & 13.5 & 10.6 \\
\hline Professionals & 15.7 & 18.8 \\
\hline Technical & 2.2 & 1.3 \\
\hline Sales & 17.9 & 15.0 \\
\hline Administrative Support & 4.9 & 12.5 \\
\hline Service & 5.8 & 30.0 \\
\hline Production/Operation/Repair & 39.9 & 11.9 \\
\hline
\end{tabular}

\section{Measures}

Respondents were identified as self-employed with no employees based on self-reported employment status in the survey. The following sections describe the measures used as variables in the study.

\section{Dependent Variable}

Annual income of the respondent measured in dollars was used as the dependent variable for hypothesis testing. This was a self-reported number collected in the survey.

\section{Independent Variables}

Designation of part time and full time, calculated using the number of hours worked in a week, were based on the U.S. Bureau of Labor Statistics's definition of part time as being anyone who works less than 35 hours a week. Number of hours worked was collected by asking respondents the usual number of hours worked in a week. Gender was self-identified. Industry codes and occupation codes were assigned by the research company based on job and employer information collected in the survey. The 14 major industry codes from the 1990 census were used to code industry. These were wholesale trade, agriculture/ forestry/fishing/mining, construction, manufacturing, retail trade, transportation/communications/utilities, business/ representative services, personal services, entertainment/ recreational services, medical services, education services, other professional services, and public administration.

The 7 major occupation codes from the 1990 census were used to code occupation of position. These included executive/administrative/managers, professionals, technical, sales, administrative support, service, and production/operator/repair. Designation of professional and nonprofessional was based on nonprofessional being anyone whose occupation was service or production/ operator/repair and professional being anyone whose occupation was executive/administrative/managers, professionals, technical, sales, and administrative support.

\section{Control Variables}

Education was measured as the highest level of schooling completed in years. Age was also measured in years.

Education, number of hours worked, and age were used as control variables in all analyses. Industry and occupation were also used as control variables in the analyses where neither were hypothesized effects.

\section{Analysis Strategy}

Hypotheses were tested using a multivariate analysis of variance (GLM in SPSS). This allowed categorical variables to be entered into the analysis as factors with discrete levels as opposed to creating a number of dummy variables. Control variables were entered into all models. Main effects where hypothesized were tested for significance and effect sizes (partial etas squared) were calculated. Additional analyses were conducted after hypotheses testing to provide further insights into the effects by gender. To shed further light on the underlying effects seen in the hypothesis testing, the means were calculated for measures that the authors felt would provide further information on what was actually going on in the data. Earned salary was calculated for males and females for each of the hypothesized subgroups, such as full time versus part time and professional 
versus nonprofessional, as well as for each industry and occupational category. Additionally, means for education, age, and dollars per hour (calculated by dividing earned salary by 52 weeks and then by hours worked a week) were calculated and tested for significant differences across gender groups.

\section{Results}

Hypothesis 1a predicted that self-employed women earn less than self-employed men. This hypothesis was supported. The annual earnings of self-employed men was $\$ 54,958$ and the annual earnings of self-employed women was $\$ 28,554$. When controlling for education, age, hours worked, industry, and occupation, there was a significant difference between the annual earnings of self-employed women and self-employed men $\left(\eta^{2}=0.07, F=24.588\right.$, $p=0.000)$. Significant control variables in the model were hours worked, education, and occupation. Hypothesis $1 \mathrm{~b}$ predicted that self-employed women who worked full time earn less then self-employed men who work full time. This hypothesis was supported. Women who were self-employed and worked full time earned significantly less (\$39,373 annually; $\$ 15.94$ per hour) than men who were self-employed and worked full time $(\$ 62,118$ annually; $\$ 23.94$ per hour). In the multivariate model controlling for education, age, hours worked, industry and occupation, self-employed women who worked full time earned less than self-employed men who worked full time $\left(\eta^{2}=0.02, F=6.898, p=0.009\right)$. Education was also significant in the model. Hypothesis $1 \mathrm{c}$ predicted that self-employed women who worked part time earn less than men who work part time. This hypothesis was also supported. Women who were self-employed and worked part time earned $\$ 18,840$ annually ( $\$ 17.63$ per hour), while men who were self-employed and worked part time earned $\$ 40,179$ annually ( $\$ 36.57$ per hour). Testing the hypothesis in a multivariate model with control variables, self-employed women who worked part time earned less than self-employed men who worked part time $\left(\eta^{2}=0.05\right.$, $F=13.289, p=0.000)$. None of the control variables were significant in the model. Means and hypothesized results for annual earnings are presented in Tables $2 \mathrm{a}$ and $2 \mathrm{~b}$.

Table 2a. Annual Earnings Means by Gender for Full-Time and Part-Time Employees

\begin{tabular}{lcccc} 
& \multicolumn{4}{c}{ FULL TIME } \\
\cline { 2 - 5 } & Salary* & \$/Hour* & Education* & Age \\
\hline Males & $\$ 62,18$ & $\$ 23.94$ & 13.0 & 45.78 \\
& $\$ 39,373$ & $\$ 15.94$ & 13.5 & 50.33 \\
\cline { 2 - 4 } & \multicolumn{2}{c}{ PART TIME } & Age \\
\hline Males & Salary* & $\$ /$ Hour* & Education & 49.88 \\
Females & $\$ 40,179$ & $\$ 36.57$ & 13.55 & 50.46 \\
\hline
\end{tabular}

$*^{*}<.05$

NOTE: The t-tests do not control for number of hours worked, education, age, occupation, or industry and should be viewed as ad hoc analyses. 
Table 2b. Multivariate GLM Analysis of Earnings by Gender

\begin{tabular}{llccccc} 
& \multicolumn{2}{c}{$\begin{array}{c}\text { Hypothesis 1a: } \\
\text { All Respondents }\end{array}$} & \multicolumn{2}{c}{$\begin{array}{c}\text { Hypothesis 1 b: } \\
\text { Full Time }\end{array}$} & \multicolumn{2}{c}{$\begin{array}{c}\text { Hypothesis 1c: } \\
\text { Part Time }\end{array}$} \\
\cline { 2 - 7 } & $\eta^{2}$ & $F$ & $\eta^{2}$ & $F$ & $\eta^{2}$ & $F$ \\
\hline Gender & 0.07 & $24.59^{* *}$ & 0.03 & $6.90^{*}$ & 0.05 & $13.29^{* *}$ \\
Hours Worked & 0.05 & $19.22^{* *}$ & 0.01 & 2.61 & 0.01 & 1.15 \\
Education & 0.02 & $6.38^{*}$ & 0.05 & $8.89^{*}$ & 0.00 & 0.01 \\
Age & 0.00 & 1.30 & 0.00 & 0.62 & 0.01 & 1.46 \\
Occupation & 0.01 & $4.74^{*}$ & 0.01 & 2.13 & 0.02 & 2.82 \\
Industry & 0.00 & 0.13 & 0.00 & 0.31 & 0.00 & 0.47 \\
\hline
\end{tabular}

${ }^{*}<.05 ; * *<.001$

NOTE: The t-tests do not control for number of hours worked, education, age, occupation, or industry and should be viewed as ad hoc analyses.

Hypothesis 2a theorized that no significant difference existed between the number of hours worked by selfemployed women who worked full time and the number of hours worked by self-employed men who work full time. This hypothesis was supported. Men worked an average of 49.9 hours, while women worked an average of 47.5 hours. Using a multivariate model with age, education, industry, and occupation as controls, there was no significant different in the number of hours worked between self-employed women who worked full time and self-employed men who worked full time $\left(\eta^{2}=0.01, F=\right.$ $1.390, p=0.240$ ). Hypothesis $2 b$ posited that women who were self-employed and worked part time worked the same number of hours as self-employed men who worked part time. This hypothesis was also supported.

Women worked on average 20.5 hours a week, while men worked on average 21.1 hours a week. When tested with a multivariate model including education, age, industry, and occupation as control variables, there was no significant difference in the number of hours worked between self-employed women who worked part time and self-employed men who worked part time $\left(\eta^{2}=0.00, F=0.189, p=0.665\right)$. It should be noted that almost twice as many self-employed men $(n=132)$ worked full time as their female counterparts $(n=74)$. As expected, more self-employed women worked part time $(n=84)$ as compared to self-employed men $(n=61)$. See means and hypothesized results for hours worked in Tables $3 \mathrm{a}$ and $3 \mathrm{~b}$.

Table 3a. Means by Gender for Full-Time and Part-Time Employees

FULL-TIME HOURS

\section{Males}

Females
49.9

47.5
PART-TIME HOURS

20.5

All comparisons are non-significant.

NOTE: The t-tests do not control for number of hours worked, education, age, occupation, or industry and should be viewed as ad hoc analyses. 
Table 3a. Means by Gender for Full-Time and Part-Time Employees

\begin{tabular}{lcccc} 
& \multicolumn{2}{c}{$\begin{array}{c}\text { Hypothesis 2a: } \\
\text { Full Time (36+ hrs) }\end{array}$} & \multicolumn{2}{c}{$\begin{array}{c}\text { Hypothesis 2b: } \\
\text { Part Time }(<36 \text { hrs })\end{array}$} \\
\cline { 2 - 5 } & $\eta^{2}$ & $F$ & $\eta^{2}$ & $F$ \\
\hline Gender & 0.01 & 1.39 & 0.00 & 0.19 \\
Education & 0.00 & 0.03 & 0.00 & 0.70 \\
Age & 0.05 & 1.04 & 0.00 & 0.25 \\
Occupation & 0.00 & 0.86 & 0.01 & 2.39 \\
Industry & 0.00 & 0.58 & 0.01 & 1.23 \\
\hline
\end{tabular}

All effects are non-significant

Hypothesis 3 predicted that across industries selfemployed women would earn less than self-employed men. This hypothesis was not supported. The main effect of gender was significant $\left(\eta^{2}=0.18, F=5.569, p=0.027\right)$, however, the interactive effect reached significance $\left(\eta^{2}=0.10, F=2.683, p=0.001\right)$. This indicates that within all industries, women were not paid less than men, but overall gender still does account for a large pay difference in many industries. Table 4a displays the hypothesized results for the gender by industry and occupation.

Table 4a.GLM Analysis of Earning Differences by Gender and Industry

\begin{tabular}{lcc} 
& \multicolumn{2}{c}{$\begin{array}{c}\text { Hypothesis 3: } \\
\text { Industry }\end{array}$} \\
\cline { 2 - 3 } & $\eta^{2}$ & $F$ \\
\hline Gender & 0.18 & $5.57^{*}$ \\
Gender X Industry & 0.10 & $2.68^{* *}$ \\
Industry & 0.49 & 0.98 \\
Occupation & 0.01 & 2.85 \\
Hours Worked & 0.07 & $22.84^{* *}$ \\
Education & 0.04 & $12.30^{* *}$ \\
Age & 0.00 & 0.30 \\
\hline
\end{tabular}

$R 2=0.324$

${ }^{*}<.05 ;{ }^{* *}<.001$ 
Women earned less than men in all but four industries - agriculture/forestry/fishing/mining, wholesale trade, entertainment/recreation, and medical services. In four industries - manufacturing, transportation/utilities, personal services, and public administration-men outearned women by more than double. Table $4 \mathrm{~b}$ displays the annual earnings by industry.

Table 4b. Mean Earnings by Gender and Industry

\begin{tabular}{lll} 
Industry & MALE & FEMALE \\
\hline Agriculture/Forestry/Fishing/Mining & $\$ 32,553$ & $\$ 46,451$ \\
Construction & $\$ 49,932$ & $\$ 40,474$ \\
Manufacturing & $\$ 87,407$ & $\$ 21,518$ \\
Transportation/Utilities & $\$ 81,993$ & $\$ 41,042$ \\
Wholesale Trade & $\$ 40,164$ & $\$ 79,179$ \\
Retail Trade & $\$ 66,795$ & $\$ 34,055$ \\
Finance/Insurance/Real Estate & $\$ 65,842$ & $\$ 24,874$ \\
Business/Repair Services & $\$ 37,241$ & $\$ 19,048$ \\
Personal Services & $\$ 91,256$ & $\$ 32,994$ \\
Entertainment/Recreation & $\$ 23,189$ & $\$ 62,339$ \\
Medical Services & $\$ 20,291$ & $\$ 32,564$ \\
Education Services & $\$ 32,076$ & $\$ 22,570$ \\
Other Professional Services & $\$ 39,436$ & $\$ 26,162$ \\
Public Administration & $\$ 98,347$ & $\$ 45,941$ \\
\hline
\end{tabular}


Hypothesis 4a predicted that across occupations selfemployed women would earn less than self-employed men. This hypothesis was supported as the main effect for gender was significant $\left(\eta^{2}=0.37, F=6.365, p=0.028\right)$, and the interactive effect of gender and occupation was not significant $\left(\eta^{2}=0.03, F=2.069, p=0.056\right.$ ). (See Table 5a for results.) Across all occupations except one-production/ operation/repair — women made less than men. In four occupations - professionals, technical, sales, and servicemen earned more than double what women earned in the same occupation. Earnings by occupation and gender are displayed in Table 5b.

Table 5a. GLM Analysis of Earning Differences by Gender and Occupation

\begin{tabular}{|c|c|c|c|c|c|c|}
\hline & \multicolumn{2}{|c|}{$\begin{array}{l}\text { Hypothesis 4a: } \\
\text { All Respondents }\end{array}$} & \multicolumn{2}{|c|}{$\begin{array}{l}\text { Hypothesis 4b: } \\
\text { Professional }\end{array}$} & \multicolumn{2}{|c|}{$\begin{array}{l}\text { Hypothesis 4c: } \\
\text { Nonprofessional }\end{array}$} \\
\hline & $\eta^{2}$ & $F$ & $\eta^{2}$ & $F$ & $\eta$ & $F$ \\
\hline Gender & 0.37 & $6.37^{*}$ & 0.05 & $9.98^{*}$ & 0.01 & 0.76 \\
\hline Occupation & 0.04 & 1.21 & 0.01 & 1.19 & 0.05 & $8.33^{*}$ \\
\hline Gender X Occupation & 0.00 & 2.07 & & & & \\
\hline Hours Worked & 0.52 & $16.99^{* *}$ & 0.14 & $28.7^{* *}$ & 0.03 & $5.20^{*}$ \\
\hline Education & 0.05 & 3.80 & 0.01 & 0.96 & 0.05 & $8.82^{*}$ \\
\hline Age & 0.01 & 0.32 & 0.01 & 0.94 & 0.03 & $4.39^{*}$ \\
\hline \multirow[t]{2}{*}{ Industry } & 0.00 & 0.10 & 0.00 & 0.00 & 0.02 & 3.88 \\
\hline & \multicolumn{2}{|c|}{$R 2=0.217$} & \multicolumn{2}{|c|}{$R 2=0.259$} & \multicolumn{2}{|c|}{$R 2=0.200$} \\
\hline
\end{tabular}

${ }^{*}<.05 ; * * .001$

Table 5b. GLM Analysis of Earning Differences by Gender and Occupation

\begin{tabular}{llc}
\cline { 2 - 3 } Occupation & MALE & FEMALE \\
\hline Executives/Administrators/Managers & $\$ 58,962$ & $\$ 31,900$ \\
Professionals & $\$ 81,825$ & $\$ 36,383$ \\
Technical & $\$ 46,550$ & $\$ 20,803$ \\
Sales & $\$ 73,993$ & $\$ 35,678$ \\
Administrative Support & $\$ 28,928$ & $\$ 19,363$ \\
Service & $\$ 51,023$ & $\$ 25,024$ \\
Production/Operation/Repair & $\$ 42,380$ & $\$ 50,252$ \\
\hline
\end{tabular}


Hypothesis 4b predicted that among professionals, women would earn less than men. This hypothesis was supported, with males having a mean salary of $\$ 69,114$ compared to females having a salary of $\$ 33,538$. Earning per hour was also significant in the ad hoc analysis (men: \$36.69 vs. females: \$22.92). When tested with a multivariate model including control variables, there was a significant difference in the annual earnings of professional self-employed men and professional self-employed women $\left(\eta^{2}=0.05, F=9.98\right.$, $p=0.004)$. Hypothesis $4 c$ predicted that among selfemployed nonprofessionals, women would earn less than men. This hypothesis was not supported. Four of the five control variables were significant in the model_occupation, hours worked, education, and age-accounting for the differences in earnings. While the mean average earnings for women in the study was less than for men, it was not significant. Table 5a displays the results for the hypothesis testing for the gender difference in annual earnings by occupation as well as professional and nonprofessional. Table $5 \mathrm{c}$ displays the means for earnings and the ad hoc analysis of dollars per hour, education, and age.

\section{Table 5c. Annual Earnings Means by Gender for Full-Time and Part-Time Employees}

\section{PROFESSIONAL}

\begin{tabular}{lcccc}
\cline { 2 - 4 } & Salary* & \$/Hour* & Education & Age \\
\hline Males & $\$ 69,114$ & $\$ 36.69$ & 13.99 & 48.84 \\
Females & $\$ 33,538$ & $\$ 22.92$ & 13.73 & 51.18 \\
\hline
\end{tabular}

NONPROFESSIONAL

\begin{tabular}{lcccc}
\cline { 2 - 4 } & Salary* & \$/Hour & Education & Age \\
\hline Males & $\$ 40,061$ & $\$ 21.23$ & 12.35 & 45.89 \\
Females & $\$ 32,098$ & $\$ 16.40$ & 12.88 & 49.05 \\
\hline
\end{tabular}

${ }^{*}<.05$

NOTE: The t-tests do not control for number of hours worked, education, age, occupation, or industry and should be viewed as ad hoc analyses

\section{Discussion}

A recent study by the American Association of University Women (2015) estimates that the overall gender pay gap for women employed as waged employees is approximately 78 percent. For self-employed women, the pay disparity is actually much worse. The estimated pay gap for self-employed women compared to their male counterparts in the current study was startling: overall selfemployed women earn 52 percent of what self-employed men earn; self-employed women who work full time earn 63 percent of what self-employed men earn who work full time; and self-employed women who work part time earn 47 percent of what self-employed men who work part time earn. While other studies have investigated the gender pay gap among self-employed workers, their results pointed to choice of industry (Hundley,
2001; Borden, 1999), choice of occupation (Hipple, 2010; Georgellis \& Wall, 2005), and number of hours worked (Becker, 1986; Hersch \& Stratton, 1994; Hymowitz, 2012) as the primary reasons for the pay disparity. The findings of the current study demonstrate that the pay gap for self-employed women exists regardless of these factors. The current study puts forth the existence of the glass cage where regardless of education, hours worked, or choice of occupation, there is a systematic gender bias in pay from which it is difficult to escape. Women begin their careers at a pay disparity from which they never recover (Weinberger, 2011). When controlling for factors that have been previously identified as the reasons for the pay disparity, there still exists a significant difference in earnings by gender for self-employed women. 
Most surprising about our results was the disparity among professional workers. As the number of professional women entering self-employment increases, one would expect the pay inequity to close as well. Some studies have found that women who are more educated and have more experience are more likely to enter into self-employment (Taniguchi, 2002; Devine, 1994), particularly women who are in the later stages of their careers and who are looking for a bridge career to retirement (Roche, 2014). After being often overlooked for senior positions due to lack of recognition, lack of informal networks and mentors, lack of career path (Mattis, 2004), and blatant discrimination due to organizational norms (Hill, 2013), many professional women are turning to selfemployment as both an escape from these push factors as well as the potential pull opportunities of being the boss and earning more (Annik \& den Dulk, 2012). However, in self-employment, the negative impact on a woman's career can potentially be more significant.

Our study found that, with no significant difference between education and age, a professional woman made 62 percent of what her male professional counterpart did on an hourly basis. One possible reason for the inequity could be that women typically have less social capital and more condensed networks, limiting their ability to generate new business and their ability to access capital needed to grow their business (Gatewood et al., 2009; Coleman, 2000). Additionally, the same gender stereotypes and biases that inhibited career advancement in corporations are also firmly rooted in the very organizations and networks that women need to access and successfully pitch (Bosse \& Taylor, 2012). Self-employed women encounter the same attitudes and biases when seeking funding for their businesses despite experience and educational levels (Bosse and Taylor, 2012). Another factor could be the very behaviors that make one successful in business. A meta-analysis on gender differences on negotiation outcomes (Stuhlmacher \& Walters, 1999) suggests that the pay disparity observed in organizations can be partially attributed to genderbased differences in terms of negotiated outcomes as these initial differences become more pronounced in the long run due to increases based on percentage of pay. Therefore, it is possible that even though women leave corporate jobs, among many other factors, due to the lower pay rates they receive from their employers, they keep on asking for less from clients or expect to be paid less than men for the same job.
Another finding from our results is the high incidence of women using self-employment as a surrogate for part-time work. Women are almost twice as likely to use self-employment as part-time work (57.7\%) as men (39.2\%). And yet women still earn significantly less in part-time selfemployment than men. Our analyses found gender to be the only significant factor that explained the difference in earnings for part-time self-employed workers. This points to the lack of meaningful part-time work in organizations whereby women can be both worker and mother.

The current study examined the most commonly cited reasons for pay disparity. In line with the Bureau of Labor Statistics report (2007), women did not work significantly fewer hours than men when classified as part time and full time. Part of the reason for the previous finding that women work fewer hours than men is that prior studies do not take into account that a large portion of women who use self-employment as a substitute for part-time work; so by choice they are working fewer hours. We chose to break the sample into part time and full time to minimize this self-selection to work less hours. The current study also found that although in some industries (wholesale trade, entertainment, medical services, and other professional services) women did make more than men, for the most part, women were at a pay disparity to men in the same industry and in the same occupation. More importantly, controlling for these industry and occupation pay disparities did not account for the difference in earnings among women and men.

The current study does have some limitations. First, the data used for this analysis was from 2008, prior to the recession. As a means of determining if this trend has continued, we examined the most recent Bureau of Labor Statistics report on earnings and self-employment and found in 2012 full-time self-employed males earned $\$ 49,521$ annually compared to self-employed females who earned $\$ 32,806$ annually while part-time self-employed males earned $\$ 29,310$ and part-time self-employed females earn $\$ 17,322$ annually (Roche, 2014). The pay gap still persisted for self-employed females in 2012. Second, the National Study of the Changing Workforce has limited information about the actual jobs individuals perform in self-employment, particularly whether individuals were working as independent contractors or actually running a stand-alone enterprise. We recognize that the collected data was self-reported via survey and as such is subject to response error. 
Additionally, we had no information about the process by which these individuals chose to become self-employed and on other financial factors (such as net worth) that may impact the ability to fund a new enterprise.

Despite these shortcomings, the results of this study point to the need for further research on a number of fronts. First, our results suggest an underlying gender bias that is more pronounced in self-employment. Future research needs to identify factors that contribute to the pay disparity between self-employed men and women outside of age, education, hours worked, and occupation. Instead of accounting for gender pay disparity, this line of research needs to investigate the reasons for the underlying gender bias in the pay gap. Second, our study found that in some industries women are outearning men. Further study is needed to understand the positive factors helping women achieve earning parity in these industries. Lastly, more research is needed with regard to women who work part time. Based on the results of our study, women disproportionately use self-employment as parttime work. The factors pushing and pulling women into part-time self-employment need to be examined in more depth. Additionally, professional women working part time experience an even wider pay gap despite the same age, education, and occupation as men. Research should address the underlying factors behind the gap and the later consequences when women try to reenter full-time employment.

\section{REFERENCES}

Acker, J. (1990). Hierarchies, jobs, bodies: A theory of gendered organizations. Gender and Society, Vol. 4, No. 2, 139-158.

Acker, J. (2006). Inequality regimes gender, class, and race in organizations. Gender and Society, Vol. 20, No. 4, $441-464$.

American Association of University Women (2015). The simple truth about the gender pay gap. Spring.

Annik, A., and den Dulk, L. (2012). Autonomy: The panacea for self-employed women's work-life balance? Community, Work and Family, Vol. 15, 383-402.

Becker, G. S. (1986). Human capital, effort, and the sexual division of labor. Journal of Labor Economics, Vol. 3, No. 1, 33-58.

Bernstein, G. and Triger, Z. H. (2010), Over-Parenting. UC Davis Law Review, Vol. 44, No. 4, 1221-1279.

Bianchi, S. M. (2000). Maternal employment and time with children: Dramatic change or surprising continuity? Demography, Vol. 37, No. 4, 401-414.

Blanchflower, D. G., \& Oswald, A. J. (1998). What makes an entrepreneur? Journal of Labor Economics, Vol. 16, No. 1, 26-60.

Borden, J. (1999). Gender inequality in wage earnings and female self-employment selection. Journal of Socio-Economics, Vol. 28, No. 3, 351-365.

Bosse, D. A., \& Taylor III, P. L. (2012). The second glass ceiling impedes women entrepreneurs. The Journal of Applied Management and Entrepreneurship, Vol. 17, No. 1, 52-68.

Budig, M. (2006). Gender, self-employment, and earnings: The interlocking structures of family and professional status. Gender and Society, Vol. 20, No. 6, 725-753.

Carland, J. W., Carland, J. A., Hoy, F. \& Boulton, W. R. (1998). Distinctions between entrepreneurial and small business ventures. International Journal of Management, Vol. 5, No. 1, 98-103.

Coleman, S. (2000). Access to capital and terms of credit: A comparison of men and women-owned small businesses. Journal of Small Business Management, Vol. 38, No. 3, 37-52.

Cox, W. (2013). Toward a self-employed nation? www.newgeography.com.

36 NEW ENGLAND JOURNAL OF ENTREPRENEURSHIP 
Devine, T. (1994). Changes in wage-and-salary returns to skill and the recent rise in female self-employment. American Economic Review, Vol 2. No. 84, 108-113.

Gatewood, E. J., Brush, C. G., Carter, N. M., Greene, P. G., \& Harte, M. M. (2009). Diana: A symbol of women entrepreneurs' hunt for knowledge, money, and the rewards of entrepreneurship. Small Business Economics, Vol. 32, No. 2, 129-144.

Georgellis, Y. \& Wall, H. J. (2005). Gender differences in self-employment. International Review of Applied Economics, Vol. 19, No. 3, 321-342.

Hersch, J. \& Stratton, L. S. (1994). Housework, wages, and the division of housework time for employed spouses. The American Economic Review, Vol. 84, No. 2, 120-125.

Hill, K. L. (2013). We've come a long way, baby, or have we? Journal of Organizational Culture, Communications and Conflict, Vol. 17, No. 2, 29-36.

Hipple, S. F. (2010). Self-employment in the United States. Monthly Labor Review, September. http://www.bls.gov/opub/mlr/2010.

Hughes, K. D. (2003). Pushed or pulled? Women's entry into self-employment and small business ownership. Gender, Work, and Organization, Vol. 10, No. 4, 433-454.

Hundley, G. (2000). Male/female earnings differences in self-employment: The effects of marriage, children, and the household division of labor. Industrial and Labor Relations Review, Vol. 54, No. 1, 95-114.

Hundley, G. (2001). Why women earn less than men in self-employment. Journal of Labor Research, Vol. 22, No. 4, 817-829.

Hymowitz, K. (2012). Why women make less than men. Wall Street Journal, April 26.

Kao, R. W.Y. (1993). Defining entrepreneurship: Past, present and? Creativity and Innovation Management, Vol. 2, 69-70.

Kotkin, J. (2012). The rise of the 1099 economy: More Americans are becoming their own bosses. Forbes, July 25.

Lombard, K. V. (2001). Female self-employment and demand for flexible, nonstandard work schedules. Economic Inquiry, Vol. 39, No. 2, 214-237.

Mallon, M. \& Cohen, L. (2001). Time for a change? Women's accounts of the move from organizational careers to self-employment. British Journal of Management, Vol. 12, 217-230.

Mattis, M. C. (2004). Women entrepreneurs: Out from under the glass ceiling. Women in Management Review, Vol. 19, No. 2, 154-163.

McKie, L. Biese, I., \& Jyrkinen, M. (2013). "The best time is now!”The temporal and spatial dynamics of women opting into self-employment. Gender, Work and Organization, Vol. 20, No. 2, 1-14.

Parker, K. \& W. Wang (2013). Modern parenthood: Roles of moms and dads converge as they balance work and family. Pew Research Center. Social and Demographic Trends.

Prottas, D. A. \& Thompson, C. J. (2006). Stress, satisfaction, and the work-family interface: A comparison of self-employed business owners, independents, and organizational employees. Journal of Occupational Health Psychology, Vol. 11, No. 4, 366-378.

Roche, K. (2014). Female self-employment in the United States: An update to 2012. Monthly Labor Review, October. http://www.bls.gov/opub/mlr/2014

Slaughter, A. (2012). Why women still can't have it all. The Atlantic, June 13. 
Smith, R. A. (2012). Money, benefits, and power: A test of the glass ceiling and glass escalator hypotheses.

The Annals of the American Academy of Political and Social Science, Vol. 639, 149-172.

Stone, P. (2007). Opting out: Why women really quit careers and head home. University of California Press.

Stuhlmacher, A. F., \& Walters, A. E. (1999). Gender differences in negotiation outcome: A meta-analysis.

Personnel Psychology, Vol. 52, No. 3, 653-677.

Taniguchi, H. (2002). Determinants of women's entry into self-employment. Social Science Quarterly, Vol. 83, No. 3, 875-893.

Warner, J. (2013). The opt-out generation wants back in. New York Times, August 7.

Weinberger, C. J. (2011). In search of the glass ceiling: Gender and earnings growth among U.S. college graduates in the 1990s. Industrial and Labor Relations Review, Vol. 64, No. 5, 949-980.

U.S. Bureau of Labor Statistics, www.bls.gov/CPS.

U.S. Bureau of Labor Statistics, U.S. Department of Labor (2007). American Time Use Report. The Economics Daily.

\section{ABOUT THE AUTHORS}

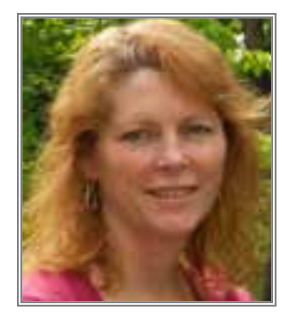

Leanna Lawter, Ph.D. (lawterl@sacredheart.edu), is an Assistant Professor at Sacred Heart University, where she teaches entrepreneurship, management, and human resources. She also consults on designing performance management systems and $\mathrm{HR}$ analytics. Her research focuses on women entrepreneurs and the impact of human resource practices on work attitudes and performance.

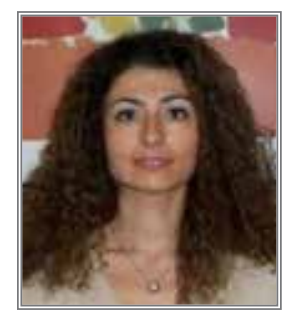

Tuvana Rua, Ph.D. (ruat@sacredheart.edu), is an Assistant Professor of Management at the John F. Welch School of Business at Sacred Heart University. Her research focuses on self-control, ethics and decision making and she has published in journals such as the Personality and Social Psychology Bulletin and Journal of Management Development.

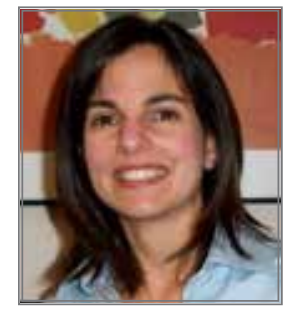

Jeanine K. Andreassi, Ph.D. (andreassij@sacredheart.edu), is an Associate Professor at Sacred Heart University. She has published primarily in the area of work-life and has published in journals such as the Journal of Managerial Psychology, Journal of Family Issues, and Cross Cultural Management: An International Journal. She also serves on the editorial board of Journal of Family Issues. 